\title{
A ESTRATIFICAÇÃO E A MOBILIDADE SOCIAL NAS COMUNIDADES AGRÁRIAS DO VALE DO PARAIBA, ENTRE 1850 E 1888.
}

\section{INTRODUÇAO}

Até fins do século XIX, o rio Paraíba é por excelência o rio do café e percorre o "vale da escravatura e das grandes fazendas" (1), o que é fácil de verificar; basta lançarmos os olhos para qualquer mapa dos fins do século XIX que assinale as produções brasileiras; remontando o curso do rio desde a foz, veremos as margens marcadas por: café, café, café, indicando o produto principal das terras que atravessa. Café, em São Fidelis, café em Cantagalo, café em Vassouras, café em Barra Mansa, café em Bananal, café em Cunha, café em Pindamonhangaba, café em Taubaté, café em Paraibuna e São Luís do Paraitinga, café em Jacareí (2).

Nos anos abrangidos por êste trabalho, a zona produtora do café no país se dividia em duas: uma que era tributária do pôrto de Santos e outra tributária do pôrto do Rio de Janeiro. A zona tributária do Rio de Janeiro englobava justamente tôda essa região do Paraíba, mais alguns municípios mineiros e espírito-santenses; a zona tributária de Santos é a zona central de São Paulo, Mogiana, Paulista, etc., cujo esplendor tinha início por volta de 1870 (3). Esta é a divisão de Affonso d'E. Taunay, que se baseava no escoamento do produto: uma parte saía pelo pôrto do Rio de Janeiro e outra parte pelo pôrto de Santos.

Folheando quer a "História do Café no Brasil", quer o livro de Louis Couty, quer os opúsculos do Barão do Paty do Alferes e o do dr. Luís Corrêa Azevedo, o que salta à vista é a uniformidade de tôda a zona percorrida pelo Paraíba, do ponto de vista

\footnotetext{
(1). - COUTY (Louis). - Le Brésil en 1884. Faro \& Lino éditeurs. Rio de Janeiro. 1884. pg. 388.

(2). - FREIRE (Olavo) e MAY (Coronel Alfredo Oscar de Azevedo). - Atlas de Geografia Universal e especialmente do Brasil. Livraria Clássica de Erancisco Alves. Rio de Janeiro. 1910.

(3). - TAUnay (Affonso d'E.). - História do Café no Brasil. Vol. VII - tomo V, parte VI. Ed. do Departamento Nacional do Café. Rio de Janelro. 1939 .
} 
das culturas, do modo de exploração da terra, dos problemas, da prosperidade e da ruína.

Os caracteres principais da economia são, como no resto do Brasil, o latifúndio e o trabalho escravo; todos os autores consultados se referem à "aristocracia dos grandes proprietários" e ao "cancro da escravidão".

"A terra, em todos os lugares acessíveis do país, está entre as mãos de uma aristocracia de grandes proprietários: os fazendeiros ( . . ) que constituem uma classe até agora tôda poderosa" (4).

"Numa fazenda tudo procedia do negro; as benfeitorias elle as construira; fôra oleiro, serrador, cavouqueiro, canalizara as aguas, abrira os caminhos, construira o engenho e fabricara muitas de suas machinas. Fôra tambem o creador dos animais domesticos. Antes do seu aparecimento alli o valor venal da terra era nullo. Assim a fazenda nada mais representava senão o trabalho escravo accumulado. Era o escravo o unico valor que naquella propriedade podia ser avaliado pelo preço do custo, fôsse o trabalhador africano ou creoulo, quasi sempre comprado" (5).

O que diferenciava essencialmente esta zona da outra, da tributária de Santos, é que os fazendeiros dela persistiam em explorar suas propriedades quase que só com o braço escravo, enquanto os fazendeiros da outra zona já em 1850 começavam a buscar e empregar imigrantes (6).

O resultado era, por volta de 1880 , as plantações do Vale se apresentarem já tôdas mal tratadas, pois além do exgotamento da terra, a falta de braços vinha contribuir para que o aspecto de ruína se alastrasse por tôda parte. De onde um pessimismo geral dos fazendeiros da zona, cujas opiniões Affonso d'E. Taunay reproduz (7), contrastando com as inovações, o dinamismo, a atividade da zona tributária do pôrto de Santos, onde a cultura cafeeira estava em pleno desenvolvimento.

Tanto Luís Corrêa de Azevedo quanto Louis Couty não se cansam de apontar aos fazendeiros da região do Paraíba o exemplo dos lavradores paulistas; porque é interessante notar, principalmente no livro dêste último, que a denominação de paulistas não abrange o pessoal da zona paulista do Vale, que é incluída entre os fluminenses, juntamente com os mineiros e espírito-santenses.

(4). - LeClerC (Max). - Lettres du Brésil. Librairie Plon. Paris. 1890. pg. 108

(5). - TAUNAY (Affonso d'E.). - ob. cit., vol. cit. tomo cit., pg. 420.

(f). - AZEvedo (Dr. Luís Corrêa de). - Da Cultura do Café - em apêndice à 3.a edição da Memoria sobre a fundaçáo e o costeio de uma fazenda na provincia do Rio de Janeiro, do Barão do Paty do Alferes. Eduardo \& Henrique Laemmert. Rio de Janeiro, 1878, pg. 272

(7). - TAUNAY (Affonso d'E.). - ob. cit., vol. cit., tomo cit., pg. 362 . 
A verdade é que a colonização, tal como começavam a praticar os paulistas da época, parava no município da capital; daí para diante, avançando para o Rio de Janeiro, era pràticamente inexistente, como o atestam tanto Affonso d'E. Taunay quanto Louis Couty; em seus livros.

Assim caracterizadas as zonas, e dada a homogeneidade da zona tributária do Rio de Janeiro, quer ela seja paulista, fluminense ou espírito-santense, deixo de limitar êste trabalho exclusivamente à parte paulista" do Vale do Paraíba e estendo-o a tôda a região que êsse rio atravessa onde se tenha plantado café, o que me permite lançar mão de uma bibliografia mais extensa.

\section{I-AS FONTES PARA O TRABALHO.}

Para se fazer um trabalho aproveitável, o primeiro passo seria evidentemente travar um conhecimento íntimo com as questões d: estratificação, classificação e mobilidade dos grupos sociais, através das obras sociológicas mais modernas, isto é, adquirir um certo conhecimento teórico da questão. O tempo, porém, não dava para tanto. Tentei suprir a falha recorrendo à "Encyclopaedia of the Social Sciences", lendo os artigos que interessassem ao assunto. De modo que as noções de estratificação e de mobilidade social em que me baseio provém dos artigos "Class", de Paul Mombert, "Social Mobility", de P. Sorokin e "Organization, social" de Robert Lowie.

Em seguida, seria necessário dar buscas em diários e assentamentos de fazendeiros da região, para saber que espécie de gente empregavam em suas fazendas, escravos ou assalariados; inquirir de assentamentos de igrejas e cartórios, inventários, testamento, contratos de compra e venda, de arrendamento de terras (se houvesse), de locação de serviços (que raramente eram feitos por escrito; mas enfim...), que nos fornecessem dados não só para a questão de classes como para a da mobilidade social. Em alforrias por testamento, por exemplo, poder-se-ia constatar a formação dessa camada de população que Louis Couty caracteriza como sendo "cinco ou seis milhões de camponeses mestiços, encontrados por tôda a parte, não apenas nas fazendas de negros do Rio ou de São Paulo, que não são mais escravos, dos quais todavia descendem" (8). Talvez topasse até com algum contrato de compra e venda que viesse comprovar as asserçốes dos autores lidos de que os fazendeiros das províncias do Sul se abasteciam de escravos nas províncias do Liorte. Sei muito bem que o mais certo seria não achar nada em materia de contratos; aquêle era ainda o tempo em que a honestidade dos contratantes dispensava escrituras e em que um simples fio de barba era o melhor dos fiadores.

(8). - COUTY (Louls). - ob. cit., pg. 105. 
Tôda essa parte do trabalho estava para mim inteiramente fora de cogitação; aqui não era só uma questão de tempo e sim também de meios.

Tive de me contentar apenas com a pesquisa bibliográfica, que a rigor deveria vir depois das fases anteriores e que ajudaria a esclarecer e ordenar os dados encontrados. E minha pesquisa bibliográfica também foi pequena, porque intervinha novamente $o$ fator tempo.

A busca se dividiu em duas partes: procurei livros de autores da época; procurei estudos sôbre a época.

Entre os autores da época, consultei os seguintes:

1 - Barão do Paty do Alferes, "Memoria sobre a fundação e costeio de uma fazenda na provincia do Rio de Janeiro", 3.a edição, 1878, Eduardo \& Henrique Laemmert, Rio de Janeiro. Publicada a primeira edição em 1860 , saía a terceira em 1878 , recomendada ao público pelos editores como um "valioso guia prático do fazendeiro".

2 - Dr. Luís Corrêa de Azevedo - Em apêndice à terceira edição da "Memoria" acima mencionada, vem o opúsculo dêste autor, escrito em 1877, especialmente para recomendar aos fazendeiros da região de Cantagalo as melhores maneira de cudiar dos cafèzais, segundo os métodos que já estavam usando os paulistas do oeste, isto é, limpeza regular, poda, emprêgo do estrume e do arado. Acha o autor que o fazendeiro brasileiro não merece o nome de lavrador; "é apenas um dono de terras e escravos, que manda plantar mudas de café, e que encarrega a êsses trabalhadores de executarem o trabalho como fôr melhor para acabar depressa e chegar-se à colheita" (9).

3 - Louis Couty', "Le Brésil en 1884" - Faro \& Lino éditeurs, Rio de Janeiro, 1884. Professor de biologia industrial que viera reger uma cadeira na Escola Politécnica do Rio de Janeiro, Louis Couty impressionou-se com o descaso em que era deixada a imigração, justamente quando a escravatura estava prestes a se extinguir. Affonso d'E. Taunay baseia boa parte de seu capítulo "A falta de braços na lavoura cafeeira" em dados dêste livro e de um outro estudo de Louis Couty: "Le café".

4 - Alfred Marc - "Le Brésil, excursion à traveurs ses 20 provinces" - édité par J. G. d'Argollo Ferrão - Paris - 1890 - Tome II. Alfred Marc era redator do jornal "Le Brésil", em Paris; o diretor, J. G. d'Argollo Ferrão, capitão de marinha reformado que lá morava, pede-lhe que, aproveitando a viagem que o jornalista ia fazer ao Brasil, redigisse um livro de informações "para colocar diante dos olhos do leitor de boa fé um quadro sincero da situação do país sob seus aspectos principais, animado do desêjo de mostrar aos europeus quanto vale êsse país, o que aí se realiza, como

(9). - AZEVEdo (Dr. Luís Corrêa de). - ob. cit., pg. 251; o grifo é do autor. 
funciona, como utiliza os recursos e as atividades que the confia o velho-mundo" (10).

5 - Charles d'Ursel - "Sud-Amérique" - E. Plon \& Cie. - Paris - 1879. O conde Charles d'Ursel foi secretário da legação belga durante mais de três anos no Brasil e teve ocasião de visitar algumas fazendas, quase tôdas elas da zona tributária do Rio de Janeiro.

6 - Max Leclerc - "Lettres du Brésil" - Librairie Plon - Paris - 1890. Este livro também foi escrito por um jornalista, enviado ao Brasil pelo "Journal des Débats", de Paris, para ver de perto o que era a revolução republicana; reune os artigos que Max Leclerc, do Brasil, mandava para o seu jornal em Paris.

7 - Eugène de Robiano - "Dix-huit mois dans l'Amérique du Sud" - 3.a edição - Librairie Plon, Paris - 1886. E' outro livro de viagens, escrito em 1879 . $O$ autor menciona ter encontrado Charles d'Ursel enquanto aqui esteve; dedica dois capítulos à vida da fazenda, visitou algumas, mas não dá o nome dos proprietários, o que é pena. No entanto, dado o pouco tempo que aqui esteve, deve ter visto as grandes fazendas clássicas, invariàvelmente mostradas aos estrangeiros, que Charles d'Ursel visitara e que os Agassiz visitaram também, isto é, as propriedades luxuosas dos viscondes de Nova Friburgo e São Clemente, as da família Lage, as do comendador Breves, a fazenda imperial de Santa Cruz, tôdas na região tributária do Rio de Janeiro.

8 - M. et Mme. Agassiz - "Voyage au Brésil" - Librairie Hachette \& Cie. - Paris - 1872. - Preparando-se para visitar a "região do Amazonas", esteve o casal de cientistas no Rio de Janeiro, onde M. Agassiz fêz uma série de conferências. Levaram-nos depois a visitar as fazendas célebres dos Nova Friburgo (na região fluminense), dos Lage (perto de Juiz de Fora) e do comendador Breves (Barra do Piraí).

9 - José de Alencar - "O tronco do ipê" - Civilização Brasileira S. A. Ed. Rio de Janeiro - 1938.

10 - Júlia Lopes d'Almeida - "A família Medeiros" - 2.a edição - Horácio Belfort Sabino, Editor - São Paulo - 1894 .

Dois fazendeiros, um professor, dois jornalistas, dois viajantes, um casal de cientistas, dois romancistas, creio que os autores estão bem variados. Se houver concordância nas descrições, acho que posso admitílas como válidas.

Os livros dos viajantes e dos romancistas, mais vivos e mais descritivos, valem como verdadeiros instantâneos da vida de então.

Quanto a estudos atuais sôbre aquela região naquela época, só dois me foram úteis:

1 - Affonso d'E. Taunay, com sua "História do Café no Brasil", da qual apenas me vali do vol. VII, tomo V, parte VI, "O problema par J. G. d'Argollo Ferrão. Paris. 1890. 2 tomos. Tomo I, pg. II. 
do braço na lavoura cafeeira", pois èra a parte que mais se relacionava com os problemas propostos e se referia aos anos de 1872 a 1889 - Ed. do Departamento Nacional do Café - Rio de Janeiro - 1939 .

2 - Sérgio Milliet - "Roteiro do Café" - Estudos Paulistas São Paulo - 1939.

\section{II - AS COMUNIDADES AGRARIAS DO VALE DO PARAI- BA E O GRUPO SOCIAL QUE AS HABITAVA.}

Este período de 1850 a 1888 pode ser dividido em duas partes distintas, de acôrdo com $o$ estudo de Sérgio Milliet: a de "pleno dinamismo", em que o ponto mais alto é o ano de 1875 , com sua colheita de 2.737.639 arrôbas, "representando 77,4\% da produção total de café daquele ano"; e a de 1875 em diante, em que "a prosperidade da zona Norte se mantém. Mas a terra dá sinais de cansaço, e a produção decresce um pouco" (11). E' a decadência que se inicia por volta de 1875 , e que vai se acelerando; se em 1875 a "produção decresce um pouco", em 1886, pelos dados do quadro de pg. 21 , do mesmo livro, a produção caira, dos $77,4 \%$ de 1854, para $19,9.9 \%$ sôbre a produção total do ano.

De modo que podemos caracterizar êstes anos de 1850 a 1888 como aquêles em que o café atinge seu ponto máximo e começa a declinar, mudando-se mais para oeste, para diante da já opulenta região campineira - marcha que redundou na morte de trodo o Vale por muitos anos.

Nos primeiros anos, as colheitas fartas autorizavam luxo nababesco e despesas quase ilimitadas; a decadência vai se dando mas a fachada continua a mesma até quase 1888 , quando libertação dos escravos completou a ruína, que não se pôde mais esconder.

"O municipio de Cantagallo, esse fertilissimo torrão de café, sem igual no Brasil, afidalgou-se na importancia de seu pessoal formou moradas esplendidas - construio senzalas vastas, - ajardinou terreiros - accrescentou machinas de beneficiar café - , endividou-se na obtenção de tudo que dá gôzo social dentro de casa, forneceu-se de optimos carros para viagens, mas descurou os plantios importantes de seus cafés, colheu, colheu, sem nunca cessar, mas tambem sem nunca indemnizar o terreno dos fructos que prelevava. Tirar e nunca repôr! Máo principio de economai é este" (12).

Mas o desperdício e a incúria que qualquer patrício enxergava, não o podiam ver os estrangeiros, que nada conheciam de café. Mais ou menos na mesma época, 1872, 1879, Mme. Agassiz e Charles d'Ursel podiam ainda escrever o que se segue:

\footnotetext{
(11). - Milliet (Sérgio). - Roteiro do Café. Estudos Paulistas. São Paulo 1939, pg. 24.

(12) . - AZEVEDo (Dr. Luís Corrêa de). - Ob. cit., pgs. 225-226.
} 
"Esta vida de fazenda, pelo menos nos seus prazeres, de que gozei, lembra os costumes encontrados nos castelos da Idade Média" (13). "Somos acolhidos com uma hospitalidade que dificilmente se encontrará igual fora do Brasil. Aqui ninguém pergunta quem somos, nem de onde vimos, mas nos abrem largas as portas" (14).

"Nova Friburgo é uma estação de veranêio. Quase tôda a região pertence a êsse rico proprietário (o barão de Nova Friburgo, um dos mais ricos capitalistas do Brasil na época) (...). De sua vila elegante (situada na fazenda Gavião), onde se goza o luxo mais rebuscado e refinado, o barão superintende a administração dc suas terras, os trabalhos numerosos que executa por todos os lados, a construção de suas estradas de ferro e a exploração de suas plantações magníficas. Uma rêde telegráfica liga seu escritório particular com tôdas as suas fazendas" (15). Mais adiante, conta o mesmo autor que a residência do barão na outra fazenda, Areas, era uma "mansão senhorial" (16) .

Por detrás da fachada soberba que ainda se mantinha, o livro do dr. Luís Corrêa de Azevedo mostra a decadência dos cafèzais . Note-se que foi escrito quase na mesma época, em 1877: "Ali, onde tudo, tudo, devia ser vida e verdura, vê-se um vasto cemitério de plantas pardacentas, e de catadura desanimadora e lúgubre" (17) . "Nós temos, nesta provincia, na freguezia de Apparecida, terrcnos que forão uberrimos e onde se colhia café à farta; o aspecto delles é hoje melancholico; extensos morros de cafeeiros apresentão largas superficies de ruinas desses arbustos, multidão de galhada secca, verdadeiros espectros que relembrão a prodigalidade com que se abatião matas, e o capricho ambicioso de possuir extensos plantios mal cultivados" (18). Cinco anos antes, estivera Mme. Agassiz nas fazendas; Charles d'Ursel as visitaria dois anos depois.

Ricas ainda, ou sentindo já os efeitos da decadência, a composição do pessoal das fazendas da zona Norte era mais ou menos a mesma para tôdas.

Affonso d'E. Taunay, baseando-se em Louis Couty, dá a seguinte relação para uma fazenda de Cantagalo: "Uma fazenda com duzentos e cincoenta escravos precisava ter administrador, boticario, guarda-livros, dois pelo menos, um feitor, maquinista e cinco ou seis capatazes" (19). E mais adiante completa: "Um administrador, geralmente, se paga à razão de conto e quinhentos a dois contos de réis annuaes, recebendo o sustento da fazenda para si

(13). - AGASSIZ (M. et Mme.). - Voyage au Brésil. Librairie Hachette \& Cie. (13). - Aaris. 1872, pg. 67.

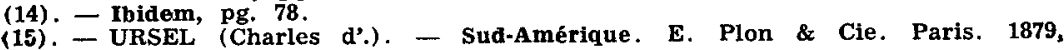
pg. 96 .

(16). - Ibidem, pg. 97 .

(17). - AzEVEDo (Dr. Luís Corrêa de ). - ob. cit., pg. 228.

(18). - Ibidem, pg. 229.

(19). - TAUNÁY (Affonso d'E.). - ob. cit., vol. cit., págs. 405-406. 
sua familia. Havia ainda os feitores e outros empregados livres cumo fôssem escrivães, officiaes de officio, encarregados do engenho ( ...). Algumas dessas propriedades tinham medico fixo" (20): Descrevera o mesmo autor, páginas atrás, a composição da fazenda Cantagalo, pertencente à condessa do Rio Novo: "Havia 170 escravos e 30 ingenuos $(\ldots)$. O conselho de administração compunha-se do diretor, sr. Manuel Ribeiro do Val, do medico, do pharnaceutico, do secretario e do padré" (21).

Os outros livros consultados corroboram estas descrições.

O barão do Paty do Alferes escreve: “... convém que o lavrador trace ou faça traçar a planta da fazenda, com designação de casa destinada à sua residência e à do pessoal livre e escravo..."; refere-se também às obrigações do administrador, às dos feitores, ao médico assistente; explica os inconvenfentes do emprêgo de colonos e conclui que a escravatura "é o cancro roedor do Imperio do Brazil que só o tempo poderá curar" (22).

M. et Mme. Agassiz, no "Voyage au Brésil", descrevem o pessoal da fazenda do comendador Breves, em Barra do Piraí: "êste domínio conta mais ou menos 2.000 escravos, dos quais uns trinta são empregados no serviço doméstico. A habitação possui todo o necessário para suprir a tão numerosa população: há uma farmácia e um hospital, uma capela, um padre, um médico" (23) .

Enquanto os Agassiz reparam mais no confôrto oferecido aos membros da comunidade, Charles d'Ursel se impressiona com a hierarquia: "Uma espécie de hierarquia administrativa distribui e vigia o trabalho; a autoridade passa então do "senhor" ao seu "administrador" e dêste aos "feitores" armados do chicote tradicional, verdadeiros chefes de esquadrões, muitas vêzes êles mesmos escravos" (24).

Eugène de Robiano não dá nenhuma descrição precisa; menciona ter encontrado, nas fazendas onde esteve, além do dono e sua família, um administrador, um capelão "encarregado de catequisar, batizar e casar os negros" e feitores (25).

$O$ pessoal que figura na fazenda do Boqueirão, descrita por José de Alencar no "O tronco do ipê" é o seguinte: administrador, feitores, capatazes, os escravos, o dono da fazenda e sua fanúlia $(26)$.

(20). - Ibidem, pg. 413 .

(21). - Ibidem, pg. 365 .

(22). - Alferes (Barão do Paty de). - Memoria sobre a fundação e costelo de uma fazenda na provincia do Rio de Janeiro. - 3.a edição. Eduardo \& Henrique Laemmert. Rio de Janeiro. 1878, pgs. 3, 20, 21, 22, 25; 0 grifo é meu.

(23). - AGASSIZ (M. et Mme.). - ob. cit., pg. 79.

(24). - URSEL (Charles d'). - ob. cit., pg. 80 .

(25). - ROBIANo Eugêne de). - Dix-huit mois dans l'amérique du sud. 3.a eđị̧ão. Librairie Plon. Paris. 1886, pgs. 50-53.

(26). - AlendCAR (José de). -o tronco do ipê. Civilização Brasileira S. A. Rio de Janeiro. 1938, pgs. 6, 156, 181. 
Temos então um conjunto de pessoas dividido em três corpos distintos: o dono da fazenda e sua família; os empregados assalariados da administração, incluindo o capelão e o médico; os escravos.

Entre as duas camadas, de empregados da administração e de escravos, existia no Brasil outra intermediária, formada de libertos, de colonos e de agregados, apontada com insistência principalmente por Louis Couty.

Os cólonos são encontrados muito raramente nessas fazendas do Vale. Affonso d'E. Taunay, baseando-se em dados fornecidos pelo holandês van Delden Laerne, menciona a existência de colonos apenas na fazenda de outro holandês, Antônio van Erven, que empregava imigrantes açorianos (27).

O barão do Paty! do Alferes, escrevendo em 1860, só se refere a colonos para se queixar de que êles “...mal se sujeitam a indemnizar seu amo, retirando-se ou evadindo-se, muitas vezes sem ter cumprido seu contráto" (28), concluindo que existia "necessidade de continuar-se com esse cancro (a escravatura), cujo preço atual não está em harmonia com a renda que delle se póde tirar" (29).

Louis Couty, quando aponta aos fazendeiros que fomentavam a colonização como exemplos para aquêles que se apegavam ao trabalho escravo, cita nomes como os do Senador Vergueiro, Antônio Prado, Queiroz Teles, todos da região campineira ou limeirense. No Vale, só acha para citar o mesmo van Erven, também nomeado por van Delden Laerne (30).

Não quero com isso dizer que não existissem colonos nas fazendas do Vale; existiam, mas em quantidade muito pequena; o normal, o comum, eram as fazendas de escravos; mas em geral todos estavam tratando de substituí-los por colonos, o que os do Vale não pensavam fazer.

Libertos e agregados, êsses sim eram encontrados em quantidade por tôda a parte.

Era muito comum os negros alforriados continuarem a residir na fazenda, cedendo-lhes o dono um pedaço de terra para a sua roça. E' o caso dos velhos Benedito e Chica, de "O tronco do ipê", "fôrros desde o dia do casamento de Mário" (31), que ficam a habitar a mesma casinha à beira do boqueirão .

Este reparo é de Charles dUrsel: "...é penoso constatar que estes sêres que o infortúnio torna interessantes, uma vez libertados não trabalham mais e não trabalharão jamais. Estas naturezas fundamente preguiçosas não se preocupam com o futuro: para viver, basta-lhes consumir os frutos da terra (...) e o ideal para êles é o farniente. Temos exemplos marcantes em tôdas as grandes propriedades, nas quais os libertos, vivendo em terrenos

(27). - TAUNAY (Affonso d'E.). - Ob. cit., vol. cit., tomo cit., pgs. 359-360.

(28). - ALFeres (Barão do Paty do). - Ob. cit., pg. 22.

(20). - Ibidem, pg. 23.

(30). - COUTY (Louis). - Ob. cit., pgs. 190, 209, etc.

(31): - AlENCAR (José de). - Ob. cit., pg. 319. 
que lhes foram cedidos, não fazem nada absolutamente e vegetam na preguiça e na bebedeira" (32).

Louis Couty é quem mais se refere a êles, reclamando contra o idealismo dos abolicionistas, que achavam que os negros continuariam a trabalhar nas fazendas, uma vez decretada a abolição: "A presença dos escravos, a presença, ao lado dos escravos, de muitos milhões de camponeses, caboclos ou antigos agregados, inativos e sem necesidades, que não são ainda cidadãos úteis pois não votam e não trabalham continuadamente, eis a causa verdadeira não só da ausência de plantações que representem de fato riqueza, como também da insuficiência dos impostos e das exportações $(\ldots)$. Queremos falar dêsses cinco ou seis milhões de camponeses mestiços, encontrados por tôda a parte, não sòmente nas fazendas de negros do Rio e de São Paulo (...). São mais do que simples escravos, dos quais muitas vêzes descendem; formavam antigamente, sob o nome de agregados, a gens dos grandes proprietários; são menos do que cidadãos porque não são eleitores, nem consumidores, nem produtores. (...). Esses camponeses atuais não se aplicam com constância ao trabalho; muito eficazes nos serviços penosos ou passageiros, entregam-se ao repouso desde que conseguem algum dinheiro, sem pensar em economias" (33).

Posso então dizer que nas fazendas do Vale do Paraíba, no período que vai de 1850 a 1888 , o pessoal comumente encontrado era: o dono das terras e sua família; o administrador e outros empregados da administração (capelão, médico, escrivão, etc.); libertos e caboclos, que englobarei sob a designação de agregados; escravos, finalmente. Deixo assim de lado os colonos, cuja quantidade, no Vale, era irrisória.

\section{III - AS DIFERENTES CAMADAS SOCIAIS ENCONTRADAS E O CONCEITO DE CLASSE.}

Examinando o grupo humano existente nas comunidades agrárias do Vale do Paraíba, precisamos saber agora se as diferentes categorias de pessoas que nelas encontramos podem ser chamadas de classes sociais .

De acôrdo com os artigos de Paul Mombert e Robert Lowie, na "Encyclopaedia of the Social Sciences", a primeira condição, a condição determinantes para que as camadas de um grupo social possam ser chamadas de classes, é a existência entre elas de mobilidade possível e relativamente fácil, seja para o indivíduo no curso dc sua vida, seja para outras unidades sociais no curso de gerações;

(32.). - URSEL (Charles d'. - Ob. cit., pg. 88.

(33). - COUTY (Louis). - ob. cit., pgs. 103, 105 e 106. 
além dêste caráter primordial, as classes sociais se dispõem geralmente numa certa hierarquia; seus membros possuem meios econômicos mais ou menos semelhantes, que condicionam um "standard" de vida semelhante. Não existindo a mobilidade entre as camadas, diz Paul Mombert, pode-se falar em castas ou em divisões por "status", nunca em classes; esta mobilidade é chamada por Sorokin de mobilidade vertical; é a existência dela que passo a investigar, através dos livros consultados.

"Esta classe de fazendeiros não é uma classe fechada, como as antigas aristocracias francesas ou russas", escreve Louis Couty. "Muito diferentes dos "lords" inglêses, aos quais são em geral comparados sem nenhuma razão, os fazendeiros não estão protegidos por nenhuma lei especial de impostos ou de herança; se representam uma aristocracia, é uma aristocracia baseada no esfôrço próprio. Todos aquêles que trabalham e economizam podem se tornar grandes proprietários no Brasil; muitas das famílias mais ricas remontam a apenas uma ou duras gerações, e estas famílias saem do povo, são do povo como tôdas as outras" (34).

No "O tronco do ipê", o barão da Espera, "fillho de um simples administrador de fazenda", ficara "orfão e em extrema pobreza"; mais tarde se tornara, numa reviravolta súbita, dono da própria fazenda em que se criara como protegido. Por outro lado, José Figueira, filho "do mais rico fazendeiro da redondeza", brigando com o pai, fica reduzido a "trabalhar de foice na sua roça", como qualquer agregado humilde (35).

Júlia Lopes d'Almeida dá também um exemplo: "Entretanto, o pai ia traçar-lhe a biografia da familia Antunes.

"Era boa gente e fina.

- Mas então por que foi elle feitor?

- Ora! isso aconteceu; são épocas; naquelle tempo não tinha recursos... hoje está bem".

Nem mesmo a classe escrava merecia o nome de casta, porque o escravo tinha meios de sair dela: a alforria, concedida ou comprada, que já se tornara bastante freqüente na época de que estamos tratando.

" $E$ ' verdade que o escravo pertence a uma classe à parte; é considerado como um inferior, quase como um animal doméstico; mas ninguém o despreza: nenhum sinal distintivo existe diferenciando o negro ou o mulato escravo do homem de côr livre; assim nas ruas, nos veículos públicos, nas igrejas, o branco acotovela o negro sem nenhuma repugnância" (37).

Uma vez livre, o negro podia subir, desde que tivesse meios para tanto; disso foi exemplo a vida de Luís Gama; vendido pelo

(34). - Ibidem, pg. 341 .

(35). - ALENCAR (José de). - Ob. cit., pgs. 71-72, 79 e 82.

(36). - ALMEIDA (Júlia Lopes d'). - A Família Medeiros - 2a. edição, Horácio Belfort Sabino, Editor. São Paulo, 1894, pg. 52.

(37). - URSEL (Charles d'). - Ob. cit., pgs. $88-89$. 
pai como escravo, veiu Luís Gama aos 10 anos para São Paulo e fêz tôda a viagem de Santos a Campinas, para ser vendido; não o foi por ser baiano. "O último que o engeitou foi o respeitável ancião Francisco Egydio de Souza Aranha, pai do fallecido marquez de Tres Rios. (...). O marquez de Tres Riós, que esteve a ponto de ter Luís para pagem, mais tarde teve-o como um dos seus amigos mais considerados" (38).

Existindo a mobilidade vertical, posso chamar as diferentes camádas da comunidade agrária de classes. Vejamos agora de que maneira se dispunham estas camadas.

$\mathrm{Na}$ base de tôda a hierarquia está um conceito de valor; a classe mais valorizada se sobrepõe à menos valorizada. A valorização pode ter as causas mais diversas, poder, prestígio, religião, etc. Mas, ocorrendo, ela se reflete nos costumes, nas instituições, nas leis, sendo a fonte dos privilégios concedidos a umas classes que não a outras. Dêsse mọdo, a classe menos valorizada, a que ocupa o último degrau da escala, é também aquela que goza de menos regalias.

Nas comunidades agrárias, o senhor tem todos os privilégios e regalias; e o conceito de prestígio, na época, não se prende à extensão das terras e sim, e muito mais, à quantidade de escravos possuídos. Aliás, a posse do escravo é que constitui riqueza e não a posse da terra: "O valor hipotecário das instalações agrícolas no Brasil, (...) é mínimo; êle não chega de modo algum a se igualar com o valor de compra do rebanho humano. Por aí se vê que não leva em conta nem a terra, nem as culturas, nem as construções, nem os diversos meios de exploração" (39).

Cultivando a terra, entregando-se a pequenas indústrias, alugados ou arrendados, os escravos é que proporcionavam aos donos a riqueza. Eles é que trabalhavam; e o pouco valor atribuído à classe passou a se refletir sôbre o trabalho. "A escravatura (...) corrompeu a noção de dever e de respeito, desonrou o trabalho, enobreceu a ociosidade, abalou a hierarquia e destruiu a disciplina social. De acôrdo com a opinião corrente, trabalhar, se submeter a uma regra qualquer, é próprio de escravo" (40).

Já encontramos então o primeiro e o último grau da escala: no tôpo, a classe que menos precisava trabalhar, que tinha maior quantidade de gente trabalhando para ela, que era a mais prestigiada e a mais valorizada; e do outro lado, a classe que não tinha nem o direito de dispor de sua própria pessoa, que era a "coisa" de alguém, que podia ser vendida ou barganhada à vontade do senhor. Entre estas duas classes, distribuiam-se o pessoal da administração e os agregados, seguindo o mesmo princípio: êstes trabalhando sem suar, trabalhando com disfarce, se aproximando as-

(38). - amaral (Tancredo do). - A História de são Paulo. - Alves \& Cia., editốres. Sáo Paulo. 1895, pg. 238.

(39) . - COUTY (Louis). - Ob. clt., pg. 88; o grifo é meu.

(40). - LECLERC (Max). - Ob. cit., pgs. 212-213. 
sim do nível mais alto, do fazendeiro, que a rizor não precisava fazer nada.

A hierarquia se dava, então, em função do trabalho. O escravo trabalhava de enxada, de sol a sol, quisesse ou não, porque não era dono de si mesmo. O agregado, o liberto, trabalhava de enxada, mas quando lhe dava na cabeça; leia-se, por exemplo, em Louis Couty: "êstes camponeses atuais (os agregados) não trabalham continuadamente; são muito bons para os serviços penosos e passageiros, mas entregam-se ao repouso assim que conseguem algum dinheiro e não pensam em economizar" (41). O pessoal da administração exercia funções de mando, que era um trabalho disfarçado. $O$ dono da fazenda superintendia, podendo, se quisesse, deixar tudo nas mãos do administrador e demorar-se na côrte, prêso à politicagem ou absorvido pelos prazeres elegantes.

Todos os senhores possuiam meios econômicos semelhantes, isto é, a posse da terra e dos escravos, como são unânimes em dizer os autores que consultei. As descrições feitas da vida nas fazendas mostram como ela se parecia em tôda essa região, variando apenas no luxo maior ou menor, de acôrdo com a riqueza maior ou menor dos proprietários. Para ilustrar a semelhança de "standard" de vida, apelo para as descrições do aspecto exterior dos fazendeiros, feitas por diferentes autores: "O senhor monta um cavalo ricamente ajaezado; para tocar o animal, serve-se de um chicote de cabo de prata e de esporas gigantescas que retinem barulhentas" (42). "(...) A riqueza dos arreios de seu cavalo, seu chicote e suas esporas de prata revelam origem nobre e abastança" (43). "Otávio (...) teve um único encontro, o de um sujeito fiel aos antigos costumes do viajor paulista: (..) botas até o joelho, esporas de prata, chapéu desabado e chicote de grosso cabo de couro; atrás delle, em respeitosa distância, galopava o pagem..." (44).

As descrições das casas-grandes de fazenda, tais como encontrei em José de Alencar (45); em Eugène de Robiano (46); em M. et Mme. Agassiz (47); em Charles d'Ursel (48); em Júlia Lopes d'Almeida (49) testemunham o teor de vida idêntico que então se levava nelas.

O pessoal da administração dependia do senhor pelo salário - laço que igualava administrador, médico, escrivão, fiscais, capelão, etc. Não podiam ter a opulência do proprietário; dependiam dêste que, além de pagá-los, lhes dava casa e comida (50). Assim como havia fazendeiros riquíssimos, outros ricos e outros apenas

(41). - COUTY (Louis). - ob. cit., pg. 106.

(42). - URSEL (Charles d'). - Ob. cit., pg. 99.

(43). - ROBIANo (Eugène de. - Ob. cit., pg. 63.

(44). - ALMEIDA (Júlia Lopes do). - Ob. cit., pg. 17.

(45). - AlenCAR (José de). - Ob. cit., pgs. 5 e 6 .

(46). - ROBIANO (Eugène de). - ob. cit., pg. 60 .

(46). - AGASSIZ (M. et Mme.. - Ob. cit., pgs. 63, 72 e 73 .

(48). - URSEL (Charles d'). - ob. cit., pgs. 26-27, 94-95, 100 e 101.

(49). - ALMEIDA (Júlta Lopes d'). - Ob. cit., pgs. 20-21.

(50). - TAUNAY (Affonso d'E.). - Ob. cit., pg. 413. 
abastados, também aqui o montante do salário permitia uma vida mais apertada ou mais folgada; mas era um tipo de vida que não se parecia com a dos fazendeiros, nem com a dos agregados.

Mais heterogênea é a situação dos agregados. Davam-lhes terrenos que cultivavam? Lidavam com pequenas criações de galinhas ou de porcos? Desempenhavam ofícios como os de carpinteiro, pedreiro, etc.? Eram "parceiros"? Em todo o caso, tinham um fundo de semelhança que era viver à custa e à sombra do fazendeiro. Em geral, se contentavam em plantar um pouco de feijão, de milho, de mandioca, que garantia seu sustento e cujas sobras rendiam os tostôes para a cachaça (que Eugène de Robiano chama de "acachas") (51); pelo menos é o que nos conta Louis Couty: "O caboclo e o negro liberto não têm necessidades; fornecem quinze ou vinte dias de trabalho e desaparecem" (52).

Em todo o caso, mesmo livres, êstes agregados não podiam ser equiparados ao pessoal da administração. "O trabalhador preso à sua tarefa, voltando todos os dias, durante o ano inteiro, ao seu trabalho", era representado pelo pessoal da administração; os agregados, os libertos, êsses "entregam-se ao repouso desde que conseguem algum dinheiro", não trabalham continuadamente (53) .

Quanto aos escravos, estão em situação de inteira e total dependência do senhor, que é quem os alimenta, veste, fornece habitação, distribui algum dinheirinho, o que, segundo o barão do Paty" do Alferes, serve "para os escravos haverem o tabaco e o fumo, de que são grandes consumidores, comprarem a comida de regalo, roupa fina, a de sua mulher se são casados, e de seus filhos", pois isso contribuia "para distrahir um pouco da escravidão e entretê-los com êsse pequeno direito de propriedade" (54).

Cotejando duas descrições de pessoas tão diversas quanto Mme. Agassiz e van Delden Laerne, vemos que as condições de vida para os escravos eram pràticamente as mesmas nas comunidades agrárias.

“A habitação possui todo o necessário para suprir a tão numerosa população: há uma farmácia e um hospital, uma capela, um padre, um médico. (...) Nossa hospedeira nos fêz visitar, certa manhã, as diferentes oficinas. (...) Aqui tôdas as meninas aprendem a costurar e muitas delas bordam e fazem renda na perfeição. Em frente desta sala, vimos uma oficina de roupas (...) com seus pedaços de lã ou de algodão que as negras cortavam e costuravam para os trabalhadores do campo. As cozinhas, as outras oficinas e os quartos dos negros estão em tôrno de um páteo espaçoso, plantado de árvores e arbustos. (...) Ali formigava de negros jovens e velhos. (..) De noite, (..) uma

(5i). - ROBIANO (Eugène de). - Ob. cit., pg. 54.

(52). - COUTY (Louis). - Ob. cit., pgs. 318-319.

(53). - Tbidem, pg. 106

(54). - Alferes (Barão do Paty do). - Ob. cit., pg. 25. 
orquestra composta de escravos pertencentes à fazenda tocou-nos boa música" (55).

"Só posso louvar o modo pelo qual os vi (aos escravos) tratados e alimentados nas fazendas onde estive. Nas grandes propriedades a comida é ótima e mesmo profusa. A vestimenta tanto no inverno como no verão é satisfatória, a alimentação dos doentes não podia ser melhor; as enfermarias e pharmacias - chefiadas na maioria dos casos por allemães - são geralmente organisacas, os cuidados medicos confiados a medicos graduados que servenı em cinco, e, até, às vezes, em oito fazendas. Na maioria destiss vi escolas primarias para os ingenuos que ahi aprendiam a lêr, escrever e contar. As meninas a coser e remendar roupa. Em alguns lugares os meninos, que mostravam geito, aprendiam música; mais tarde formarão bandas" (56).

De tudo quanto ficou dito, posso concluir que havia uma estratificação por classes nas comunidades agrárias do Vale do $\mathrm{Pa}-$ raíba e que a distribuição dos indivíduos pelas diferentes classes se fazia em função dos meios econômicos.

Mobilidade social, para Sorokin, é tanto o movimento de indivíduos ou grupos de uma posição para outra no espaço ou na escala social, como a circulação de objetos, valores e traços culturais. Não está no espírito do trabalho, todavia, encarar o problema sob outro aspecto que não o de indivídus ou grupos.

Sorokin distingue duas espécies de mobilidade: a vertical, que $\dot{e}$ a passagem de um indivíduo ou grupo de uma camada para a outra, e que já verifiquei existir nas comunidades agrárias do Vale no item anterior; e a horizontal, que é a mudança do indivíduo ou do grupo ocorrendo no mesmo nível social, na mesma camada, mobilidade no espaço, em suma.

Esta mobilidade é assinalada, em traços gerais, por Sérgio Milliet: "Mesmo assim, oito lustros bastam para abarrotar de cafeeiros todo o Vale do Paraíba e parte das terras mais férteis das regiōes próximas da capital, colonizadas pelo açúcar. (...) Passados 19 anos o panorama novo nos apresenta aspectos de pleno dinamismo. 2.737.639 arrôbas de café enriquecem a zona Norte, cuja população aumenta concomitantemente de $40 \%$. Nova geração ascende e temos deante de nós um quadro inteiramente diverso. A prosperidade da zona Norte se mantém. A população porém ainda beneficia das condiçốes favorâveis e aumenta de mais ,60\%" (57).

De onde vinha todo êste povo?

Não eram colonos imigrantes, que dificilmente se fixavam nas fazendas do Vale, como nos mostra Affonso d'E. Taunay (58).

(55). - AGASSIZ ( $M$, et Mme.). - Ob. cit., pgs. 7980 .

(56). - TAUNAY (Affonso d'). - Ob. cit., pgs. 442 e segs.

(57). - MILlieT (Sérglo). - Ob. cit., pgs. 23, 24 e 27; o grifo é meu.

(56). - TAUNAY (Affonso d'E.). - ob. cit., tomo $V$, vol. VII, parte VI. 
Dessas fazendas, só uma empregava colonos açorianos, a de Antônio van Erden, também citada por Louis Couty, (59). Continuando na comparação que estabelece entre as condições do Vale e do Oeste paulista, mostra Affonso d'E. Taunay que lá, ao lado do escravo, havia o trabalho do colono, nas fazendas do visconde de Indaiatuba, do barão da Fonseca, nas fazendas Montes Alverne, Montevidéu, Santa Veridiana, Ibicaba, etc., - exemplo que não era seguido no Vale de maneira apreciável.

Não havendo correntes imigratórias, tendo cessado o tráfico de escravos entre a Africa do Sul e o Brasil, como se explica êsse aumento da população do Vale de $40 \%$ em 19 anos?

E' que o Norte brasileiro passara a vender escravos, e caros, para as plantações do Sul.

"Os proprietários das províncias do Norte, não tendo muita necessidade dêles (escravos) para as suas explorações agrícolas, estão a vendê-los em quantidade aos plantadores de café, que os compram por preços muito elevados" (60) .

"A diminuição real da mão de obra produtiva do Brasil foi ameaçada, até agora, pelas migrações de escravos do Norte para o Sul" (61).

Júlio Belo, nas suas "Memórias de um senhor de engenho", conta que a pior ameaça que se podia fazer a um cativo, em Pernambuco, era dizer: "vou vender você p'r'o café, isto é, "vou vender você a um fazendeiro de café" (62).

De 1880 em diante, porém, a diminuição dêstes negócios veio dificultar ainda mais a situação dos fazendeiros do Vale, que lutavam contra a falta de mão de obra; é que os abolicionistas tentavam por todos os meios limitar o tráfico inter-provincial.

"Em agosto de 1880, o antigo ministro e deputado por São Paulo, Moreira de Barros, propusera na Camara a interdição absoluta do comercio de escravos interprovincial (...) As provincias do Norte, a quem a escravatura causava mais inconvenientes do que lucros, tentavam vender os escravos ás do Centro, produtoras de café, para, em seguida, insistir na emancipação imedia- ta, medida que não lhes causaria damno. Nestas circunstancias, embora tal proposta não fôsse acceita, diversas circuscripções depois de 1881 e 1882 tomaram medidas para restringir o tráfico interprovincial" (63).

Esta, uma das causas do aumento da população no Vale. Por analogia com o que se observou depois em outras regiões, deve ter havido ali também, nos primeiros anos de prosperidade, o mesmo fenômeno que se deu em seguida nas terras ubérrimas de Ribeirão Prêto e que hoje se vê em relação às terras do Norte do Paraná:

(59). - CoUTY (Louis). - ob. cit., pg. 319.

(60). - URSEL (Charles d'). - Ob. cit., pg. 79.

(61). - COUTY (Louis). - Ob. cit., pg. 13.

(62). - BELO (Júlio). - Memória de um senhor de engenho. Livraria José

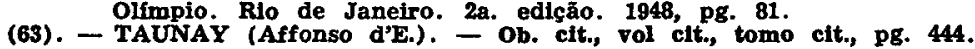


a afluência de fazendeiros de terras cansadas, buscando outras novas e melhores.

Extinto o tráfico escravo da Affrica para o Brasil, houve grande desemprêgo de capitais; nada de estranhar que muitos dêles fôssem empregados na compra e exploração de propriedades agrícolas; ora, nessa época era a cultura do café que estava em plena florescência e na região do Vale; a fazenda de café era, portanto, o emprêgo mais seguro e remunerador de capital. Mais tarde, lá para 1878,1880 , o fenômeno será contrário no Vale, como revelam as queixas do dr. Luís Corrêa de Azevedo, formuladas já em 1877: "Em lugar de se extasiar a lavoura do Rio de Janeiro( nos contos das Mil e Uma Noites dos cafesais de Botucatú, de Jahú, de Casa Branca, etc., etc., bom seria que ella deixasse de lado a narrativa dessas maravilhas, só propria de desoccupados, e se entregasse de corpo e alma a todos os processos da lavoura que alguns bons e distintos Paulistas iniciarão e que neste escripto são apontados" (64). E mais adiante: "A inspecção simples é bastante para nos indicar que ali ha falta de nutrição, que o terreno é secco e árido, que a terra mirrada não fornece camada alimentar às raizes e aos troncos. (...) Estes indicios depreciando as terras fazem morrer nos donos a esperança de bons resultados, e ei-los em demanda de novas paragens para derrubar matto, queima-lo, planta-lo" (65).

Este, ppis, é um primeiro tipo de mobilidade horizontal - a vinda de escravos do Norte para o Sul.

Há a considerar mais um tipo de mobilidade, que encontrei nas páginas de Affonso d'E. Taunay. Analisando, sempre baseado em van Delden Laerne, a situação das fazendas tributárias do Rio de Janeiro, a quase tôdas aplica a frase: "as lavouras excedem aos braços nelas disponiveis". E conta então que muitas lançavam mão de escravos alugados, como as de São Marcos, de Trimonte, de Sant'Anna, de Ibytira. A exceção era uma só: do major Francisco Halfeld, "a única das fazendas visitadas pelo nosso autor neerlandez cujo proprietario julgava ter escravos em demasia" (66).

$E$ ' interessante notar que, não obstante o aumento rápido de população, tôda a lavoura da região sofria de falta de braços; eram "lavouras demasiado grandes para o numero de captivos" (67).

Os escravos alugados provàvelmente vinham das cidades, vilas, povoações, pois onde mais buscá-los se todos os latifúndios acusavam falta de gente para o trabalho?

\footnotetext{
(64). - AZEvedo (Dr. Luís Corrêa de). - Ob. cit., pg. 267; o grifo é nosso.

(65). - Ibldem, pgs. 244-245.

(66). - TAUNAY (Affonso d'E.). - Ob. cit., vol. cit., tomo cit., pgs. 361, 362,

367 e 368 .

(67). - Ibidem, pg. 362 .
} 
Charles d'Ursel diz o seguinte: "Graças a êsses preços elevados os pequenos proprietários, nas cidades e no campo, podem alugar seus escravos por preços que constituem lucros fabulsos; assim, um negro ou uma negra são uma fonte de lucros da mesma forma que um burro ou um cavalo alugado por dia, por mês ou por ano. $O$ aluguel de um trabalhador bom é de 75 a 100 francos por mês, ou seja, dá um lucro anual de um milhar de francos..." (68).

Lembro-me de um trechinho de D. Casmurro, de Machado de Assis, em que Bentinho conta ao amigo Escobar que a mãe possuia muitos escravos: "alguns andam ganhando na rua, outros estão alugados. Não era possível ter todos em casa" (69).

De modo que, em linhas gerais, a mobilidade horizontal nas comunidades agrárias do Vale do Paraíba se caracterizaria por: até 1880, grande corrente de escravos vindos do Norte do país; até 1870 , mais ou menos, movimento de senhores, das cidades ou de outras províncias, buscando as terras férteis da região para plantar café; de 1870 em diante, início de um movimento contrário, movimento de fuga da região, que foi se alargando, se alargando, até culminar com o abandôno de tôda a cultura de café no Vale e de todo o Vale por muitos anos; movimento de escravos alugados da cidade para as fazendas, devido à falta de braços na lavoura, também de $1870 \mathrm{em}$ diante, porque até 1860 ainda fala o Barão do Paty do Alferes na "abundância de braços captivos... que esquiva o trabalhador assalariado do cultivo de nossos campos" (70).

\section{$V$ - TERMINADA A ANALISE, A SINTESE.}

"O pensamento compreende um movimento duplo. Observai o homem de ciência ou o filósofo: realizam sua obra alternando análises e sínteses. E' preciso que haja, de início observação e discernimento; mas uma vez que se multipliquem os objetos sob o esfôrço analítico do espírito, é preciso que êsses objetos dissociados se olhos de todos. (...) O pensamento completo implica nesse duplo unam novamente; é preciso que suas conexões tomem relêvo aos movimento: separação e união" (71).

Dividi as comunidades agrárias do Vale do Paraíba em classes sociais e mostrei que na região existiam as mobilidades vertical e horizontal. Esta divisão, porém, serve apenas de esquema para a compreensão da vida que então se levava. Na realidade, as classes não se apresentavam separadas nem marcadamente delimitadas; seus contornos eram vagos, e, salvo a classe escrava, me-

(68). - URSEL (Charies d'). - ob. cit., pg. 86.

(69). - ASSIS (Machado de). - Dom Casmurro, H. Garnier. Rio de Janeiro. 2.a edição, pg. 264.

(70). - ALFERES (Barāo do Paty de). - ob. cit., pgs. 22-23.

(71). - LEUBA (James H.). - Psychologie du mysticisme religleax. Librairie Félix Alcan. Paris. 1930, nota à pg. 9. 
lhor desenhada, as outras três penetram umas pelas outras, sem linhas de demarcação fixas.

O tamanho das propriedades agrícolas, separando muito as fazendas, apertava os liames que uniam as classes, de modo que o membro de uma delas tinha relações estreitas com os membros de tòdas as outras.

Mesmo a classe escrava, cujo contôrno é mais claro devido à falta de liberdade de seus membros, vivia dentro da casa do senhor, Farticipando de sua vida e de seus prazeres. E' o que espanta grandemente o viajante Charles d'Ursel: "Uma dia, gabava eu a uma amável fazendeira a beleza de suas mulatas; no mesmo instante, ela mandou chamá-las, fê-las se alinharem diante de mim e foi enumerando as graças e qualidades de seu rebanho feminino. A propósito de cada uma, ia dizendo a senhora uma brincadeira ou fazendo qualquer observação, o que tudo me deixava embaraçado, embora as interessadas não parecessem de modo algum humilhadas pela exibição. No dia seguinte, quando eu ainda me impressionava com a distância social incomensurável em que ficam colocadas as pobres criaturas devido a êsse modo de agir, aconteceu que, como fôssemos brincar de noite de cabra-cega ou de esconde-esconde, a dona da casa e suas filhas não se acharam em número suficiente para animar o brinquedo. Mandaram logo chamar as mulatas da véspera, que se puseram a brincar conosco com tôda a naturalidade, sem que tal procedimento embaraçasse ninguém!..." (72) .

Este trechinho simboliza perfeitamente o modo por que se passavam as coisas: a maneira de proceder da fazendeira, a princípio, indica a divisão, a diferença, a distância social entre uma classe e outra; para, no fim de tudo, se apagar, unidas as classes no mesmo brinquedo.

Nas páginas de "O tronco do ipê", José de Alencar dá exemplos, a cada passo, desta interpenetração. Destaco a descrição do passeio de Adélia, Alice e Mário pela fazenda, sob a guarda das mucamas Eufrosina e Felícia e do pagem Martinho, na qual se lê esta conversa: - "Nhanhã, isto são modos? Tomara que sinhá saiba; exclamou a Eufrosina. - Onde já se viu uma menina trepar nas árvores? No Rio de Janeiro só quem faz isso é menina á tôa! observou a Felícia.

O pagem também saiu-se: - Eu tiro, nhanhã; diga o que quer, que tu tiro. Uma moça faceira tem seu pagem para servir a ela" (73). A familiaridade da conversa mostra o grau de intimidade entre as mucamas, escravos, e as meninas, filhas do dono da fazenda.

Era esta intimidade que impresionava mais os viajantes estrangeiros que por aqui passavam. $O$ duro senhor de escravos,

(72). - URSEL (Charles d'). - Ob. cit., pgs. 90-91.
(72). - ALENCAR (José de). - Ob. cit., pgs. 20-21. 
dominador e áspero, de olhar de fogo e chibata nas mãos se revestia, ao contrário do que esperavam, de um aspecto paternal, embora sem abdicar dos rigores da disciplina.

A questão "classe" se complica também com a questão "status", que contribui para amenizar a escravidão e roer as arestas da hierarquia. Nada impede, por exemplo, que a mucama Eufrosina dê ordens ao administrador, sem nem sequer pedir licença à senhora e pondo-se no logar desta: “. . a a Eufrosina, cujo teiró continuava, mandou logo em nome da baroneza aviso ao administrador para fazer amarrar o fujão e rapar-lhe a cabeça" (74). Para dar tais ordens, valia-se a mucama de sua posição privilegiada de mucama de estimação, que a coloca, apesar de escrava, acima do próprio administrador, homem livre.

Assim, não bastava pertencer a uma classe de nível mais elevado para que o indivíduo fôsse considerado; era preciso também que dentro dessa classe êle possuisse uma posição de certo valor. Se fôssemos classificar o compadre Domingos Paes, do mesmo romance "O tronco do ipê", êle caberia na classe do vigário ou do administrador; no entanto, era tratado de resto por todos, inclusive mucamas e pagens; o negro escravo Pai Benedito era tratado com um respeito e consideração que o sr. Domingos Paes não alcançàva.

A respeito da valorização do "status" entre os escravos, notase que três fatôres são preponderantes: as tarefas executadas, a idade, o aspecto físico. Pai Benedito, o negro velho, era respeitado até pelo senhor. $O$ negro do eito e a escrava lavadeira não tinham a importância do pagem e da mucama. Escrava bonita, escrava clara, era separada para o serviço de dentro; algumas até, como a Isaura de Bernardo Guimarães, recebiam certa educação. A propósito desta valorização da beleza, veja-se o diálogo de $\mathbf{E u}-$ frosina e Martinho: " $\_$- Deixa êste tição! acudiu a Eufrosina. ........ - Tição!... tição é seu pai de você, negro cambaio e bichento que veio lá de Angola... Cada beiço assim! hi! Hi!... A Eufrosina, cega de raiva, atirou-se ao pajem, que fugia-lhe ao redor da mesa, exasperando a mucama com as caretas que the fazia: - Cada beiço assim, como orelhas de porco... Tapurú era mato... chegava a sair pelos olhos... Eu te esgano! (75).

$E$, diante das relações entre as classes, Charles d'Ursel conclui: "O laço que existe entre o senhor e o escravo é de natureza bizarra e difícil de definir; é talvez um sentimento do mesmo gênero que une um ao outro o homem e o animal destinado a ajudá-lo no seu trabalho e partilhando, por assim dizer, da sua existência. Nada dá idéia mais justa destas relações do que ver os filhos de escravos admitidos na vida da família, mais ou menos no

(74). - Ibidem, pg. 126.

(7F). - Hidem, pgs. 218-219. 
mesmo grau em que, entre nós, participam cães e gatos da vida comum. Os sentimentos demonstrados para com êsses moleques contém um pouco da afeição dos pais pelos filhos, porém se parecem muito mais com o carinho do dono pelo cãozinho preferido. Tudo isso é tão diferente de nossas idéias européias que devemos nos abster de julgar, porque julgaríamos injustamente" (76).

Antes, porém, definira melhor a natureza dêstes laços, ao escrever: "Eles (os escravos) são como membros de uma grande família com a qual sua existência se identificou" (77).

De fato, laços de família, laços de afeição é que dominavam em geral, deixando na sombra os laços de autoridade e de posse. E é por isso que, em "Esaú e Jacob", quando da concessão do título de barão ao Santos, Machado de Assim escreve: "Os próprios escravos pareciam receber uma parcella de liberdade e condecoravam-se com ella: Nhã Baroneza!" exclamavam saltando. E João puxava Maria, batendo castanholas com os dedos: "Gente, de quem é esta creoula?" - "Sou escrava de Nhã Baroneza!" (78). Regozijavam-se como se fôssem membros da família.

Se, como diz Robert Lowie, a natureza dos laços é que determina os tipos de unidade social (79), esta unidade social que examinamos - uma comunidade agrária no Vale do Paraíba - pertencia ao tipo patriarcal. Os laços que uniam os diferentes membros eram familiares, ou de tipo familiar; e o significado do têrmo patriarca, que encontramos nos dicionários - velho venerável rodeado de família numerosa - é justamente ilustrado pela figura do fazendeiro, englobando a "família numerosa" dêstes escravos e agregados.

Examinando ao vivo nos romances da época e nas narrações dos viajantes, a vida nestas comunidades rurais não apresentava, pois, o aspecto simplificado e esquemático que é a conclusão do item III dêste trabalho; apresentava, sim o aspecto de uma grande família. Os elementos básicos eram os discriminados no item III; constituiam, porém, nas referidas comunidades, a realidade, da mesma forma que o esqueleto é realidade para o corpo humano: sustenta-o, dá-lhe forma, mas os músculos, os nervos ,os órgãos, tudo quanto o reveste, cobre e anima, lhe modifica totalmente $o$ aspecto exterior.

\section{CONCLUSÃO}

E' o mais difícil. Que fecho por a um trabalho cujo objetivo era estudar ligeiramente (porque para estudar longamente nem um ano bastava) uma questão que, superficialmente, todos já co-

(7c). - URSEL (Charles d'). - Ob. cit., pg. 90.

(77). - Ibidem, pg. 84 .

(78). - ASSIS (Machado de). - Esaí e Jacob. H. Garnier. Rio de Janelro. 2.a edição. 1904, pg. 68.

(79). - LOWIE (Robert). - Organization social, in Encyclopaedia of the Social sciences. 
nhecem? Porque sem grande esfôrço todo o mundo, com leitura de romances e de livros de História do Brasil, pode dizer quais eram as classes nas comunidades agrárias brasileiras.

Para finalizar, em vez de numerar as conclusões parciais que terminam cada capítulo, acho mais interessante apontar um problema com que topei nas leituras: a diferença de mentalidade entre os fazendeiros do Vale do Paraíba e do Oeste Paulista, que se nota principalmente na atitude que tomavam em relação à imigração e aos melhoramentos introduzidos na cultura do café.

E' Louis Couty quem mostra melhor a diferença: "Em todos os lados, neste vale do Paraiba, vale da escravatura e das grandes fazendas, se formam associações, em Rezende, em Barra Mansa, São Fidelis, em Valença, em Cantagalo, por tôda a parte. De todos os lados, o mesmo grito se levanta: a situação é grave; já condenada pela lei libertadora de 1871, o antigo edifício econômico desmorona; é preciso tentar alguma coisa que impeça o esmagamento, na queda, dos produtores atuais, que não têm tempo de modificar sua mão de obra e seu modo de exploração. E' preciso fazer alguma coisa; o que? Não se sabe o que, ainda; e se nos limitássemos às notícias sumárias que os jornais nos dão de tais reuniões, poder-se-ia crer que estamos diante de uma efervescência passágeira, sem objetivos e sem alcance nenhum. (...). Quando dissemos que São Paulo podia servir de exemplo às outras regiões do Brasil, desejosas de caminhar para diante, muitos de nossos leitores podem ter pensado que havia um êrro da nossa parte, pois entre as regiões do café, é esta província a única que se mostra aparentemente indiferente aos acontecimentos atuais, sem apresentar neste momento nem reuniões, nem clubes, nem agitação de espécie alguma. Esta oposição tão marcante se explica simplesmente pelo fato de ter São Paulo ultrapassado a fase de agitação e de luta, para abordar a fase mais fecunda da aplicação prática $(\ldots)$. A homens de grande mérito, mas já velhos, como os Souza Queiroz e os Indaiatuba, que começaram em 1850, cercados de geral indiferença, as duas reformas, do maquinário agricola e do povoamento, instalando ao mesmo tempo nas fazendas máquinas e colonos, o clube de Campinas unia elementos mais jovens como os Geraldo Rezende, os Queiroz Teles, os Tibiriçá, os Lacerda, que logo tomaram a chefia do admirável desenvolvimento desta província" (80).

Este artigo é de junho de 1884; mas em dezembro de 1884, os fazendeiros do Vale do Paraíba ainda se perdiam em discussões estéreis, nada tinham resolvido, como se vê do final de outro artigo: "Então os grandes proprietários (...) e principalmente os do Rio e de Minas, que nada fizeram ainda, pensarão talvez nas medidas que são necessárias para a transformação do trabalho e da propriedade" (81).

(80). - COUTY (Louis). - Ob. cit., pgs. 388-398, 392-393; o grifo é meu.

(8i). - Ibidem, pg. 23; o grifo é meu. 
Estes fazendeiros, quase todos titulares do Império, dominando a política, consideravam suas fortunas sólidas e indestrutíveis, embalando-se também na ilusão de que os escravos, quando bem tratados pelos senhores, continuariam a trabalhar para êles, apesar dos avisos de Louis Coutyl: "Afora algumas exceções individuais, os negros da fazenda, uma vez libertados, cessam de produzir" (82).

Além disso, imbuidos de preconceitos os mais diversos, asfixiavam a imigração por meio de decretos absurdos; assim paralisada, não podia a imigração dar bons resultados e a falta de êxito se refletia então no pessimismo dos fazendeiros do Vale, que encontramos reproduzido nas páginas da "História do Café no Brasil" de Affonso d'E. Taunay (83), e que levava o dr. Luís Corrêa de Azevedo, fazendeiro em Cantagalo, a escrever: “... a colonização e a imigração, entidades possiveis e ambicionadas, nossos habitos, nossas contendas, nossas irregularidades e nossa inconstancia as repellem" (84).

E' êsse mesmo Luís Corrêa de Azevedo, porém, quem louva os fazendeiros do Oeste de São Paulo por seguirem o exemplo do senador Vergueiro, "de saudosa memória, o respeitável estadista que mais tinha a peito o futuro dessa província", e que "arcou com impossíveis e destruio impedimentos sérios com que o Govêrno the tapava o caminho evangelisador" (85) que conduzia a essa mesma colonização e imigração.

Talvez a diferença seja explicada por um prolongamento, no tempo, do espírito bandeirante: os homens do planalto não temiam a aventura das inovações, enquanto os do Vale, seguindo na esteira dos primeiros portuguêses, o que queriam era o lucro fácil e sem riscos, ou, no dizer do mesmo Luís Corrêa de Azevedo, o que querinm era "colher, colher, sem nunca cessar, mas tambem sem nunca indemnizar o terreno dos fructos que prelevavam" (86).

Ou talvez - o que é bem mais provável - esteja ela na diferença econômica entre os fazendeiros do Vale e os do Oeste paulista. Os primeiros, titulares do Império, representavam a burguesia latifundiária com fumos de nobreza; os segundos, "interessados nos Bancos e sociedades anônimas comerciais e industriais", formavam uma burguesia comercial (87). Tinha esta burguesia comercial todo o interêsse em acabar com a escravidão, pois "para organizar o mercado interno de que necessitava, urgia demolir o tipo social de trabalho servil" (88), assim como desenvolver a colonização estrangeira. Os fazendeiros do Vale seriam os fazendeiros ùnicamente fazendeiros; o que não era de admirar, pois, quando do

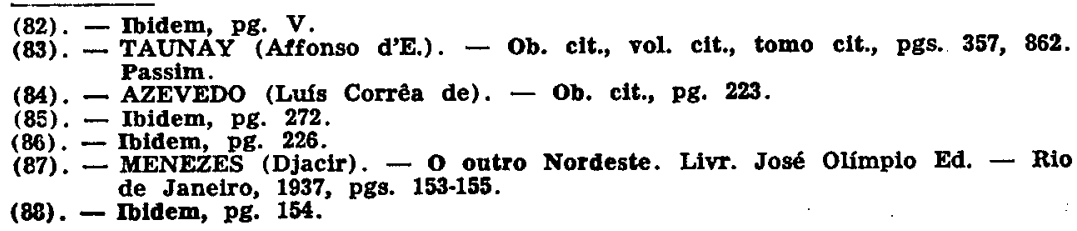


esplendor do café, seu lucro se esvaia em luxos e superfluidades; mais tarde, decadentes as terras, lutando com dificuldades, não tinham mais o que empregar em outras atividades remuneradoras. Os fazendeiros do Oeste, mais frugais e modestos, cultivando terras frescas, puderam desviar capitais para sociedades anônimas e bancos, criaram novos interêsses que os impeliam a pugnar pela abolição - que lhes obstruia os passos para o alargamento do mercado interno.

Seja como fôr, quando, em 1844, reunindo-se em clubes de lavoura, tentaram os fazendeiros do Vale uma saída para o desmoronamento total do seu sistema de produção, era tarde; não se salvaram e a libertação dos escravos acelerou ainda mais a ruína. Do êrro dêles, cortesãos, foi bode expiatório o velho Imperador, se bem que, pela sua falta de visão, tivesse boas culpas no caso.

Bem notou Max Leclerc, jornalista francês enviado ao Brasil para ver de perto o que era aquela revolução republicana que de uma hora para a outra despedira a família imperial - muito embora outorgue ao velho Pedro II uma lucidês de espírito que estava longe de possuir: "As medidas preparatórias para a grande reforma da abolição foram tomadas há vinte anos já, e quando o têrmo se aproximou, quando 0 momento decisivo estava às portas, o imperador hesitou. Nesse período de tempo, nada fizera para ajudar os plantadores a atravessarem a crise, para encorajá-los a preparar e realizar a substituição da mão de obra escrava pela mão de obra livre, - transformação essencial para o futuro do país; a imigração, único meio eficaz para que se podia apelar, foi encaminhada quase contra a sua vontade. Foi a falta capital de seu reinado, o grande êrro dêsse espírito em geral tão lúcido: não soube ver que a abolição, se não fôsse francamente anunciada, preparada abertamente e tornada inofensiva pela adição prévia de uma grande corrente imigratória, poderia se transformar num desastre co qual a monarquia seria apontada como responsável" (89).

MARIA ISAURA PEREIRA DE QUEIROZ Licenciảda em Ciências Sociais (U.S.P.).

(89). - LECLERC (Max). - Ob. cit., pgs. 189-190. 